\title{
STUDI FITOREMEDIASI LOGAM TIMBAL (Pb) DAN KADMIUM (Cd) OLEH TANAMAN KAYAMBANG (Salvinia molesta)
}

\author{
Jacson Victor Morin ${ }^{1}$, Darma Santi ${ }^{2}$ \\ ${ }^{1,2}$ Prodi Kimia Jurusan Kimia FMIPA UNIPA \\ Jl. Gunung Salju Amban, Manokwari-Kode Pos: 98214 \\ e-mail: 1.j.morin@unipa.ac.id, 2.d.santi@unipa.ac.id
}

\begin{abstract}
Study phytoremediation of lead (Pb) and cadmium (Cd) by kayambang plants (Salvinia molesta) has been studied. This study assessed the ability of plants to absorb $\mathrm{Pb}$ and $\mathrm{Cd}$ which is influenced by the addition of various metal and NPK fertilizer on the medium containing the test solution. Samples of plants were interacted with NPK fertilizer, Pb and $C d$. The variations of NPK $1 \mathrm{mg} / \mathrm{L}, I, 5 \mathrm{mg} / \mathrm{L}, 2,5 \mathrm{mg} / \mathrm{L}$ and $10 \mathrm{mg} / \mathrm{L}$ and the variations of $\mathrm{Pb}(100 \mathrm{mg} / \mathrm{L}, 400 \mathrm{mg} / \mathrm{L}$ and $800 \mathrm{mg} / \mathrm{L})$ and cadmium $(50 \mathrm{mg} / \mathrm{L}, 100 \mathrm{mg} / \mathrm{L}$ and $\quad 200$ $\mathrm{mg} / \mathrm{L}$ ). Optimum $\mathrm{pH}$ for growing the Kayambang plants (Salvinia molesta) is a range $\mathrm{pH}$ of 6-7. Observations were made every 7 days until the day of $35^{\text {th }}$, by measuring levels of $\mathrm{Cd}$ and $\mathrm{Pb}$ after the interaction of plants (roots, non-roots and growing media).

The results showed that the $\mathrm{Pb}$ and $\mathrm{Cd}$ accumulation are higher at the root compared to non-root (stem and leaf). Effect of NPK fertilizer is very evident in the heavy plant where increasing levels of NPK fertilizer plant, the more heavy weight. The average value of FT in kayambang plants (Salvinia molesta) $>1$, then the plant can be used as a phytoremediator agent. The highest value FT of $\mathrm{Pb}$ is 11.22 and shown on condition [NPK] $10 \mathrm{mg} / \mathrm{L},[\mathrm{Pb}] 100 \mathrm{mg} / \mathrm{L}$ at day of $21^{\text {th }}$ and for highest value FT of Cd is 9.57 and shown on condition [NPK] $10 \mathrm{mg} / \mathrm{L},[C d] 100 \mathrm{mg} / \mathrm{L}$ and day of $35^{\text {th }}$.
\end{abstract}

Keywords: phytoremediation, Kayambang, Lead (Pb), Cadmium (Cd)

\begin{abstract}
ABSTRAK
Studi fitoremediasi timbal $(\mathrm{Pb})$ dan kadmium $(\mathrm{Cd})$ oleh tanaman kayambang (Salvinia molesta) telah dipelajari. Penelitian ini mengkaji kemampuan tanaman dalam menyerap $\mathrm{Pb}$ dan Cd yang dipengaruhi oleh penambahan berbagai logam dan pupuk NPK pada media yang berisi larutan uji. Sampel tanaman diinteraksikan dengan pupuk NPK, $\mathrm{Pb}$ dan $\mathrm{Cd}$. Variasi NPK $1 \mathrm{mg} / \mathrm{L}, \mathrm{I}, 5 \mathrm{mg} / \mathrm{L}, 2,5 \mathrm{mg} / \mathrm{L}$ dan $10 \mathrm{mg} / \mathrm{L}$ serta variasi $\mathrm{Pb}(100 \mathrm{mg} / \mathrm{L}, \quad 400$ $\mathrm{mg} / \mathrm{L}$ dan $800 \mathrm{mg} / \mathrm{L}$ ) dan $\mathrm{kadmium}(50 \mathrm{mg} / \mathrm{L}, 100 \mathrm{mg} / \mathrm{L}$ dan $200 \mathrm{mg} / \mathrm{L})$. PH optimal untuk pertumbuhan tanaman Kayambang (Salvinia molesta) adalah berkisar antara 6-7. Pengamatan dilakukan setiap 7 hari sekali sampai hari ke 35, dengan mengukur kadar Cd dan $\mathrm{Pb}$ setelah interaksi dengan tanaman (akar, non akar dan media tanam).

Hasil penelitian menunjukkan bahwa akumulasi $\mathrm{Pb}$ dan $\mathrm{Cd}$ pada akar lebih tinggi dibandingkan non akar (batang dan daun). Pengaruh pemberian pupuk NPK terlihat pada beratnya tanaman, dimana semakin tinggi kadar pupuk NPK tanaman maka semakin berat bobot tanaman. Nilai rata-rata FT pada tanaman kayambang (Salvinia molesta) $>1$, selanjutnya tanaman tersebut dapat digunakan sebagai agen fitoremediator. Nilai FT dari $\mathrm{Pb}$ tertinggi adalah 11,22 dan ditunjukkan pada kondisi [NPK] $10 \mathrm{mg} / \mathrm{L},[\mathrm{Pb}] 100 \mathrm{mg} / \mathrm{L}$ pada hari ke-21 dan untuk nilai FT tertinggi dari Cd adalah 9,57 dan ditunjukkan pada kondisi [NPK] $10 \mathrm{mg} / \mathrm{L}$, [Cd] $100 \mathrm{mg} / \mathrm{L}$ dan hari ke-35.
\end{abstract}

Kata Kunci: Fitoremediasi, Kayambang, Timbal (Pb), Kadmium (Cd) 


\section{PENDAHULUAN}

Perkembangan ilmu pengetahuan dan teknologi, termasuk perkembangan industri telah sangat meningkatkan derajat kehidupan manusia. Selain banyaknya manfaat yang dapat dinikmati oleh manusia, efek samping dari kegiatan industri yang semakin maju adalah bertambahnya limbah atau produk limbah yang mencemari air, udara dan tanah. Bahan limbah yang melimpah dari industri telah mengakibatkan kerusakan lingkungan yang serius, hal ini ditambah lagi dengan aktivitas penduduk dunia yang meningkat tajam. Oleh karena itu, upaya serius perlu dilakukan untuk mengatasi pencemaran yang semakin parah untuk menjaga kualitas lingkungan yang baik dan berkelanjutan.

Kelompok limbah yang dapat mencemari dan menurunkan kualitas lingkungan adalah limbah logam berat. Yang termasuk limbah logam berat seperti: $\mathrm{Cu}, \mathrm{Cd}, \mathrm{Zn}, \mathrm{Pb}, \mathrm{Cr}$ dan $\mathrm{Hg}$ banyak ditemukan di alam dan sangat sulit terdegradasi (Hancock, 1996). Oleh karena itu dengan semakin banyaknya perilaku industri dan manusia yang tidak ramah lingkungan akan semakin memperburuk kerusakan akibat penimbunan logam berat yang dapat bersifat racun.

Secara umum hampir semua logam berpotensi sebagai pencemar lingkungan dan toksik bagi organisme jika konsentrasinya di lingkungan melebihi ambang batas tertentu. Menurut Freedman (1995), logam berat seperti perak (Ag), kadmium (Cd), kromium $(\mathrm{Cr})$, timbal $(\mathrm{Pb})$, kobalt $(\mathrm{Co})$, tembaga $(\mathrm{Cu})$, besi $(\mathrm{Fe})$, seng $(\mathrm{Zn})$ dan unsurunsur yang lebih ringan seperti aluminium (Al), arsen (as) dan selenium (Se) memiliki potensi besar untuk organisme yang mengakibatkan efek toksik.

Jenis-jenis limbah industri yang mengandung logam antara lain industri soda timbal, tekstil, pemurnian (pengolahan) minyak bumi, pelapisan logam, baterai timbal dan industri cat (Haryadi, 1996). Selain limbah industri, pencemaran logam timbal juga berasal dari penggunaan bahan bakar oleh mesin kendaraan bermotor dan mesin industri, limbah rumah tangga dan pertambangan.

Keberadaan ion logam berat di perairan dengan konsentrasi yang relatif tinggi menjadi racun bagi kehidupan di perairan tersebut. Masuknya logam berat ke lingkungan dapat bersumber dari dua sumber utama yaitu aktivitas manusia dan kejadian alam. Pelapukan batuan, aktivitas vulkanik, partikel debu atmosfer, merupakan aktivitas alam yang dapat menyebabkan masuknya logam berat ke dalam tanah dan lingkungan perairan. Sedangkan aktivitas manusia seperti aktivitas penambangan yang dilakukan, praktik pertanian yang tidak terkontrol, limbah rumah tangga, limbah industri, dan lain-lain dapat menjadi sumber utama masuknya logam ke lingkungan. Namun demikian, kegiatan penambangan masih menjadi sumber keberadaan logam terbesar di lingkungan (Darmono, 1995). Dalam konsentrasi yang relatif rendah, logam yang dimaksud akan diserap oleh organisme air tingkat rendah, seperti plankton, dan kemudian terakumulasi di dalam sel. Jika organisme perairan yang lebih tinggi, seperti ikan, mengonsumsi organisme ini dalam kadar rendah, penumpukan logam berat di dalam tubuh ikan akan terjadi. Jika akhirnya ikan dikonsumsi manusia, maka dapat menimbulkan gangguan kesehatan yang serius, seperti gangguan saraf otak pada anak, gangguan ginjal akut dan dapat berujung pada kematian.

Pada dasarnya logam berat dalam air limbah dapat dipisahkan dengan berbagai cara, yaitu cara fisika, kimia dan biologi (Wisjnuprapto, 1996). Pengolahan air limbah biologis 
memanfaatkan kemampuan akumulasi logam berat dalam tubuh organisme. Cara pemisahan logam berat banyak diterapkan selama ini merupakan sarana hidroksidanya, dilanjutkan dengan proses fisik yaitu proses pengendapan. Menurut Harris dan Remelow (1990), artinya tidak dapat mengendapkan logam berat seperti timbal, kadmium dan merkuri secara sempurna. Proses fisika yang umum dilakukan adalah adsorpsi, misalnya dengan karbon aktif dan filtrasi menggunakan membran. Walaupun dengan teknik tersebut dapat memisahkan pengendapan logam dalam jumlah yang relatif besar, namun konsentrasi logam yang tersisa pada air limbah masih melebihi konsentrasi yang tersirat. Oleh karena itu perlu dikembangkan beberapa cara lain termasuk kemungkinan pemanfaatan kemampuan beberapa mikroorganisme dalam menyerap logam berat.

Dalam penelitian ini dipelajari penyerapan ion timbal dan kadmium menggunakan tanaman Salvinia molesta yang dipengaruhi oleh variasi NPK dan waktu kontak. Konsentrasi ion timbal dan kadmium pada tanaman akan diukur menggunakan Spektrofotometer Serapan Atom (SSA) Perkin Elmer merek 3110.

\section{METODE}

\section{Prosedur Kerja}

Proses fitoremediasi diawali dengan persiapan tanaman dengan diaklitimasi tanaman setelah diambil dari pengambilan sampel. Aklitimasi berlangsung selama seminggu dengan menggunakan media hasil aquades dan tidak diberikan pupuk. Setelah aklitimasi kimiawi yaitu dengan menambahkan bahan kimia yang dapat mengendapkan logam berat sebagai

terpilih memiliki ukuran yang relatif sama (panjang daun 1-2 cm, panjang akar 3-6 cm).

Media tanam yang digunakan mengandung larutan polutan $\mathrm{Pb}$ dan $\mathrm{Cd}$ serta pupuk NPK. Variasi $\mathrm{Pb}$ dan $\mathrm{Cd}$ digunakan untuk $[\mathrm{Pb}] 100 \mathrm{mg} / \mathrm{L}, 400$ $\mathrm{mg} / \mathrm{L}$ dan $800 \mathrm{mg} / \mathrm{L}$ sedangkan untuk [Cd] $50 \mathrm{mg} / \mathrm{L}, 100 \mathrm{mg} / \mathrm{L}$ dan $200 \mathrm{mg} /$ L. Variasi pupuk NPK digunakan untuk setiap media yang mengandung $\mathrm{Pb}$ dan Cd yaitu $1 \mathrm{mg} / \mathrm{L}, 1,5 \mathrm{mg} / \mathrm{L}, 2,5 \mathrm{mg} / \mathrm{L}$ dan $10 \mathrm{mg} / \mathrm{L}$. Panen tanaman setiap 7 hari selama 35 hari. Pengukuran kadar logam, $\mathrm{Pb}$ dan $\mathrm{Cd}$ pada akar dan dilakukan non akar (batang dan daun). Bobot tanaman mempengaruhi variasi pupuk NPK dan variasi logam $\mathrm{Pb}$ dan $\mathrm{Cd}$ serta pengamatan morfologi tanaman juga dilakukan pada penelitian ini.

\section{HASIL DAN PEMBAHASAN}

\section{Pengaruh NPK terhadap adsorpsi}

logam $\mathrm{Pb}$ dan $\mathrm{Cd}$ di akar dan non-akar a. Penyerapan logam di akar

Berdasarkan penelitian yang dilakukan tanaman Salvinia molesta mampu menyerap kadar $\mathrm{Pb}$ dan $\mathrm{Cd}$ serta kemampuannya sangat dipengaruhi oleh pupuk NPK. Selain itu [NPK] $10 \mathrm{mg} / \mathrm{L}$ pada media yang mengandung $[\mathrm{Pb}] 800$ $\mathrm{mg} / \mathrm{L}$ pada hari ke 7 menunjukkan konsentrasi $\mathrm{Pb}$ yang terserap $287,5 \mathrm{mg} / \mathrm{kg}$ dan hari ke 35 mencapai 356,72 mg/kg seperti terlihat pada Gambar 5.1. 


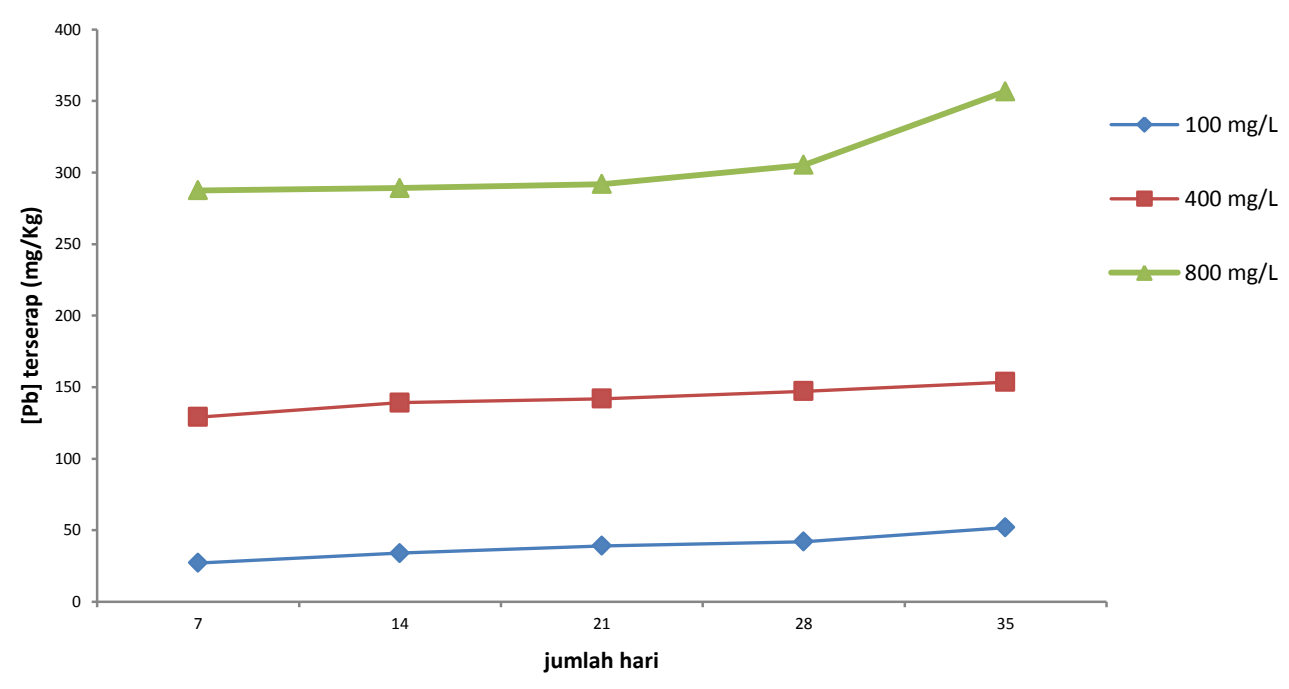

Gambar 5.1 Pengaruh [NPK] $10 \mathrm{mg} / \mathrm{L}$ terhadap adsorpsi logam $\mathrm{Pb}$ oleh tanaman S. Molesta

Penambahan $\mathrm{Pb}$ logam $800 \mathrm{mg} / \mathrm{L}$ dan NPK $1 \mathrm{mg} / \mathrm{L}$ menunjukkan bobot basah tanaman hari ke-14 (16,37 gram), hari ke$21(14,34$ gram $)$ dan hari ke-28 (8,02 gram). Keadaan morfologi tanaman (warna daun dan bentuk akar tanaman) menunjukkan bercak coklat pada hari ke 21 dengan penambahan $800 \mathrm{mg} \mathrm{Pb} / \mathrm{L}$. Begitu pula dengan penambahan pupuk NPK $15 \mathrm{mg} \mathrm{L}$ dan $25 \mathrm{mg} / \mathrm{L}$, yaitu saat diinteraksikan dengan kadar $\mathrm{Pb} 800$ $\mathrm{mg} / \mathrm{L}$.

Serapan logam Cd oleh tanaman Salvinia molesta ditunjukkan dengan penambahan pupuk NPK $10 \mathrm{mg} / \mathrm{L}$ mampu menyerap logam konsentrasi $\mathrm{Cd}$ sebesar $200 \mathrm{mg} / \mathrm{L}$ mulai hari ke-7 $(21,04 \mathrm{mg} / \mathrm{L})$ dan hari ke$35 \quad(44,24 \mathrm{mg} / \mathrm{L})$. Seperti yang ditunjukkan pada Gambar 5.2.

Pada umumnya tanaman akan menyerap unsur hara yang larut dalam air dan dari tanah melalui akar (Fitter dan Hay, 1991). Penurunan serapan logam oleh tanaman S.molesta $\mathrm{Pb}$ disebabkan kurangnya pembentukan biomassa yang disebabkan oleh kurangnya asupan pupuk NPK mineral yang digunakan sehingga pembentukan metalotionin sangat kecil jika dibandingkan dengan perlakuan penambahan pupuk NPK yang lebih besar. Apabila jumlah senyawa di dalam tanaman S.molesta metalotionin berkurang berdampak pada akar yang mengalami kerontokan rambut akibat tidak berfungsinya rangsangan pertumbuhan akar karena rusaknya fungsi enzim perangsang yang tercemar logam $\mathrm{Pb}$, sehingga tanaman tersebut tidak terserap secara optimal ke dalam protein pengikat logam $\mathrm{Pb}$ pada tumbuhan. 


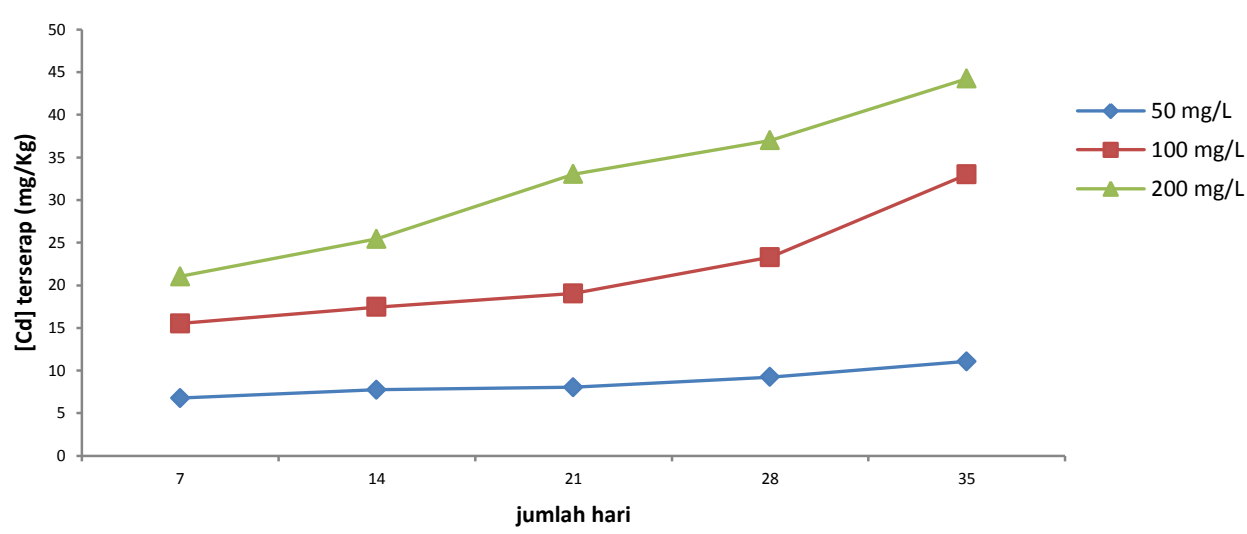

Gambar 5.2 Pengaruh [NPK] $10 \mathrm{mg} / \mathrm{L}$ untuk adsorpsi logam Cd oleh tanaman S. Molesta

Interaksi yang diduga terjadi antara kation logam dengan biomassa tumbuhan dapat terjadi melalui pertukaran ion (lemah dan kuat) dan ikatan hidrogen. Mekanisme pertukaran ion pada tumbuhan S.molesta terjadi ketika gugus karboksilat $(\mathrm{COOH})$ pada asam amino mengalami deprotonasi karena adanya ion hidroksida $(\mathrm{OH}-)$, sehingga gugus tersebut berubah menjadi karboksilat bermuatan negatif (COO-) yang sangat reaktif terhadap mengikat dengan $\mathrm{Pb}^{2+}$ dan $\mathrm{Cd}^{2+}$.

Mekanisme pembentukan ikatan hidrogen memberikan peran yang sangat besar, karena logam $\mathrm{Pb}^{2+}$ dan $\mathrm{Cd}^{2+}$ berada dalam keadaan tidak kompleks dengan $\mathrm{OH}$. Ikatan hidrogen terjadi antara dua atom yang memiliki elektronegativitas tinggi dengan hidrogen yang bersifat prototik. Oleh karena penyerapan logam $\mathrm{Pb}^{2+}$ dan $\mathrm{Cd}^{2+}$ pada biomassa dalam media air, mekanisme pembentukan ikatan hidrogen diharapkan memberikan kontribusi terbesar. Adanya kandungan serat kasar dalam komposisi tanaman $S$. molesta sebagai yang dikenal sebagai selulosa merupakan salah satu residu yang diidentifikasi dapat berikatan dengan ion $\mathrm{Pb}^{2+}$ atau $\mathrm{Cd}^{2+}$. Protein dan polisakarida memegang peranan yang sangat penting dalam proses adsorpsi ion logam berat dimana juga terjadi ikatan kovalen dengan gugus amino dan gugus karbonil. Sehingga diduga S.molesta juga memiliki kemampuan untuk mengikat ion logam. Berdasarkan hasil tersebut dapat diketahui bahwa tanaman $S$. molesta dapat menyerap timbal dan kadmium yang terkandung dalam air seiring dengan peningkatan penambahan variasi pupuk NPK yang diberikan. Penyerapan timbal dan kadmium dapat terjadi karena pada saat tanaman menyerap unsur hara dan air seringkali tanaman juga menyerap berbagai unsur lain di dalam air. Jika atom logam memiliki ukuran lebih kecil dari ukuran bukaan pori akar tanaman, maka akan langsung diserap oleh tanaman s.molesta. Agar tumbuhan dapat menyerap logam tersebut maka logam tersebut harus dibawa ke dalam larutan di sekitar akar (rhizosfer) dengan beberapa cara, tergantung dari jenis tumbuhannya yaitu dengan cara menurunkan $\mathrm{pH}$ atau pengeluaran zat pengkhelat, dalam hal ini berupa fitokhelatin. Setelah logam dibawa ke dalam sel akar, selanjutnya logam tersebut harus diangkut melalui jaringan transporter, yaitu xilem dan floem ke bagian tumbuhan lain.

Molekul khelat yang dapat berfungsi dalam mengikat logam dialam yang dihasilkan oleh tumbuhan yaitu glutathione (Zhu et al. 1999 dalam Priyanto dan Prayitno, 2006). Setelah ion logam $\mathrm{Pb}$ dan $\mathrm{Cd}$ masuk ke dalam akar maka tumbuhan akan mencoba untuk mencegah keracunan $\mathrm{Pb}$ dan $\mathrm{Cd}$ yang terdapat dalam sel dengan cara 
detoksifikasi. Detoksifikasi dapat dilakukan dengan menimbun logam beracun pada bagian-bagian tanaman seperti akar atau non-akar. Kadmium dan mengikat $\mathrm{Cd}$ dan $\mathrm{Pb}$ (Cobbett dan Goldbroughh, 2002 dalam Gratao et al. 2005). Fitokhelatin akan berperan sebagai pembawa logam cadmium dan logam kadmium akan terikat dalam sitosol kemudian ikatan logam tersebut akan dibawa ke dalam vakuola. Didalam vakuola logam $\mathrm{Pb}$ dan $\mathrm{Cd}$ dibuat tidak beracun atau ikatannya menjadi stabil secara kimia, sehingga tanaman tetap dapat tumbuh dengan baik karena proses metabolisme tidak terganggu.

\section{b. Penyerapan logam pada non-akar (batang dan daun)}

Berdasarkan hasil pengukuran kadar $\mathrm{Pb}$ yang diserap non akar (batang dan daun), menunjukkan peranan konsentrasi NPK yang besar diberikan timbal dapat didetoksifikasi pada tanaman oleh suatu famili peptida kaya sulfur yang disebut fitokhelatin yang mampu

sangat nyata, yaitu tanpa pemberian kadar NPK (0 mg/L), tanaman S. molesta hanya mampu menyerap konsentrasi $\mathrm{Pb}$ maksimum $800 \mathrm{mg} / \mathrm{L}$ sampai hari ke-14. Pada variasi konsentrasi NPK $1 \mathrm{mg} / \mathrm{L}$, $1,5 \mathrm{mg} / \mathrm{L}$ dan $2,5 \mathrm{mg} / \mathrm{L}$, tanaman mampu menyerap konsentrasi $\mathrm{Pb} \quad 800 \quad \mathrm{mg} / \mathrm{L}$ sampai hari ke-28. Namun dengan peningkatan variasi kadar NPK $10 \mathrm{mg} / \mathrm{L}$, menunjukkan tanaman menyerap kadar $\mathrm{Pb}$ sebesar $800 \mathrm{mg} / \mathrm{L}$ dari hari $\mathrm{ke}-7$ $(124,3 \mathrm{mg} / \mathrm{L})$ sampai hari ke-35 $(201,92)$ (gambar 5.3). Hal ini juga dipengaruhi oleh asupan nutrisi sebagai penyusun biomassa yang ada pada tanaman sehingga proses detoksifikasi oleh senyawa metionin dapat mengikat lebih banyak logam yaitu $\mathrm{Pb}$.

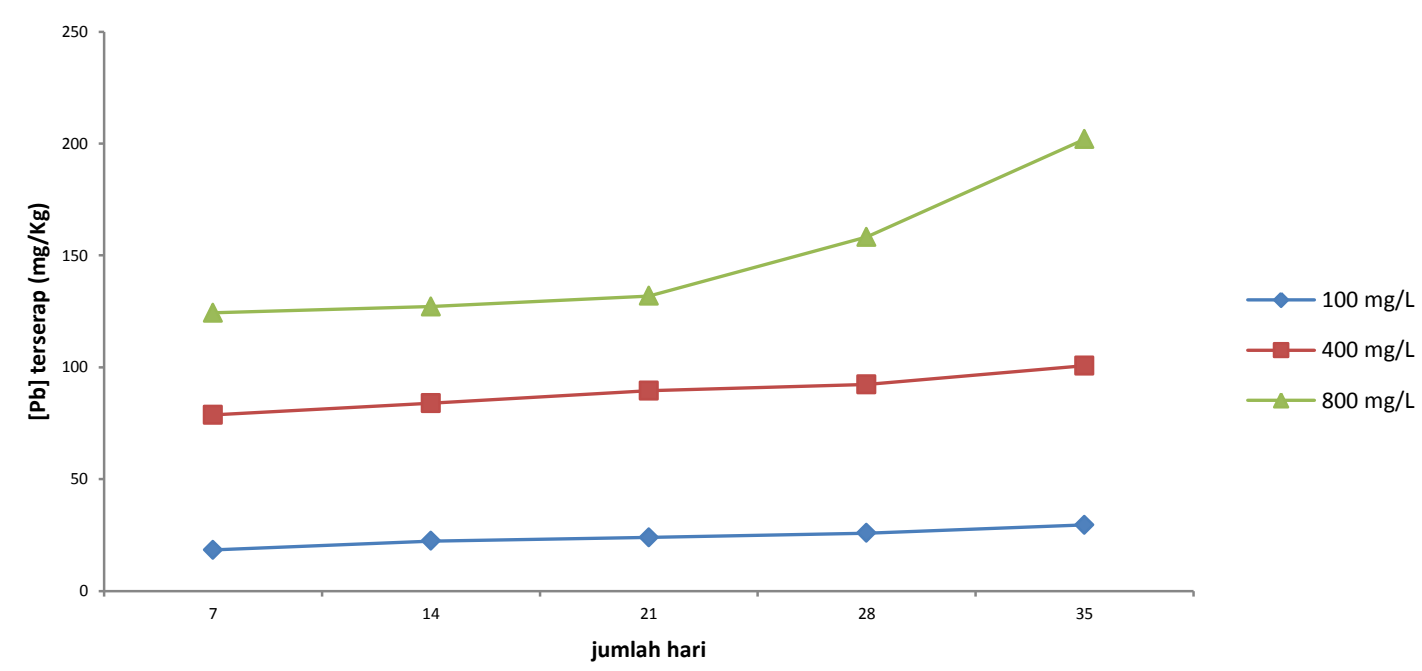

Gambar 5.3 Pengaruh [NPK] $10 \mathrm{mg} / \mathrm{L}$ terhadap adsorpsi logam $\mathrm{Pb}$ oleh tanaman $S$. Molesta

Hal serupa juga terjadi pada absorpsi logam Cd dimana penambahan Cd $200 \mathrm{mg} / \mathrm{L}$, menunjukkan tanaman Salvinia molesta menyerap logam Cd dari hari ke $7(21,04 \mathrm{mg} / \mathrm{L})$ 
sampai hari ke 35 (44,24 mg/L) serti ditunjukkan pada Gambar. 5.4.

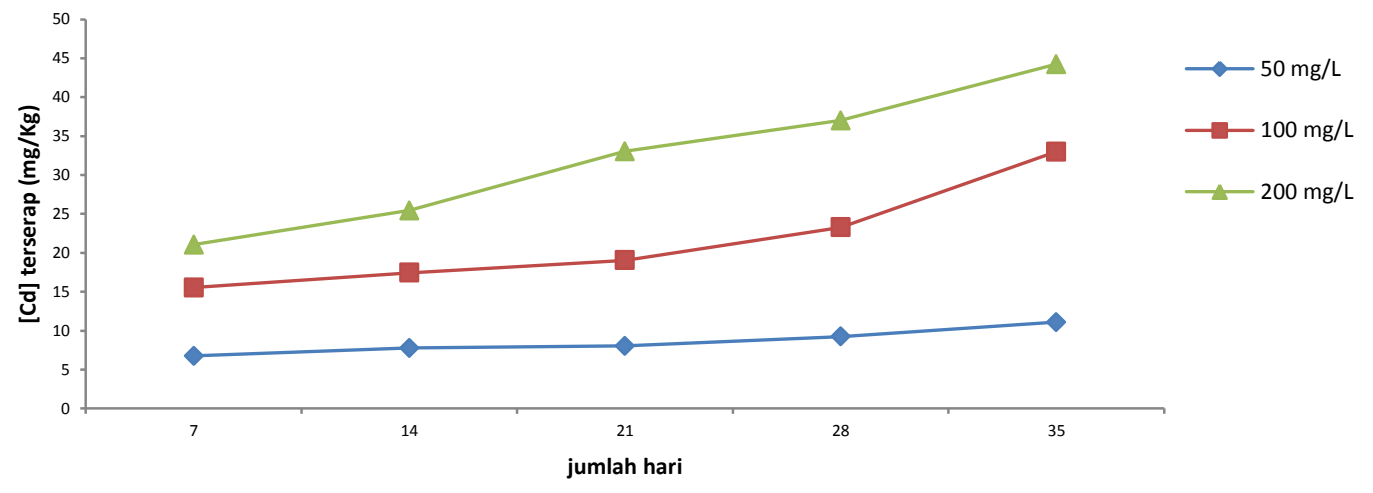

Gambar 5.4 Pengaruh [NPK] $10 \mathrm{mg} / \mathrm{L}$ untuk adsorpsi logam Cd oleh tanaman S. molesta

Tanaman S.molesta dapat mengakumulasi timbal dan kadmium pada non akar (batang dan daun) melalui proses difusi, kemudian ion $\mathrm{Pb}$ dan $\mathrm{Cd}$ akan diikat oleh fitokhelatin yang merupakan polipeptida. Ikatan ionik fitokhelatin ini kemudian akan dibawa ke dalam vakuola. Ion yang terikat oleh fitokhelatin tidak beracun lagi, sehingga tanaman tetap dapat tumbuh dengan baik dan masih dapat menyerap timbal dan kadmium dalam air dalam jumlah banyak, sebaliknya tanaman akan merusak daun yang terlihat bercak coklat tua pada permukaan daun terjadi kerontokan daun. Hal tersebut disebabkan ketahanan tanaman terhadap penumpukan logam $\mathrm{Pb}$ sudah pada batas kejenuhan dimana terjadi penumpukan logam dalam jaringan tanaman yang menyebabkan gangguan metabolisme tanaman dalam menyerap unsur hara, termasuk senyawa logam berat. Dimana proses pembentukan fitokhelatin tidak lagi diproduksi karena kekurangan asupan hara (NPK) sebagai pembentuk biomassa tanaman. Hal ini juga didukung oleh morfologi tanaman Salvinia molesta yang mengalami kerontokan rambut akar dan perubahan warna daun hijau segar pada permukaan daun berubah menjadi bercak coklat hingga tanaman menjadi mati seperti yang dikemukakan oleh Gardea, 2005.

Table 5.1 Impact of heavy metals in plants

\begin{tabular}{cl}
\hline Metal & \multicolumn{1}{c}{ Efek } \\
\hline $\mathrm{Cd}$ & $\begin{array}{l}\text { Mengurangi perkecambahan biji, kadar lemak, dan pertumbuhan; } \\
\text { menginduksi produksi fitokelatin }\end{array}$ \\
& $\begin{array}{l}\text { Menurunkan aktivitas enzim dan pertumbuhan tanaman; } \\
\text { menyebabkan kerusakan membran, klorosis dan kerusakan akar }\end{array}$ \\
$\mathrm{Cr}$ & Menghambat fotosintesis, pertumbuhan tanaman dan proses reproduksi \\
$\mathrm{Cu}$ & Mengurangi aktivitas fotosintesis, penyerapan air dan enzim antioksidan \\
$\mathrm{Hg}$ & $\begin{array}{l}\text { Mengurangi perkecambahan biji, produksi protein, klorofil dan enzim; } \\
\mathrm{Ni}\end{array}$ \\
$\mathrm{Zn}$ & $\begin{array}{l}\text { Menguranginan asam amino bebas } \\
\text { meningkatkan pertumbuhan tanaman dan rasio ATP/klorofil. }\end{array}$ \\
\hline
\end{tabular}


Selain itu pemberian pupuk NPK yang lebih tinggi akan meningkatkan produksi biomassa tanaman S. molesta hal ini juga sesuai dengan penelitian yang dilakukan oleh Juhaeti, 2007 ditunjukkan pada Tabel 5.2 dimana beberapa tanaman air termasuk S. molesta melakukan variasi penanaman dengan beberapa jenis pupuk dan pertumbuhan tanaman berpengaruh nyata. bentuk bobot basah, khususnya penggunaan pupuk NPK tanaman yang menghasilkan produksi biomassa tertinggi.

Akumulasi logam $\mathrm{Pb}$ dan $\mathrm{Cd}$ pada tanaman Salvinia molesta lebih dominan pada akar tanaman tersebut dibandingkan dengan non akar sama halnya dengan penelitian yang dilakukan oleh Mukti, 2008 tentang serapan logam pada tanaman dimana akar eceng gondok berfungsi sebagai organ penyerap dan menyalurkan unsur hara ke unsur lainnya. Sesuai dengan fungsinya, maka akar akan menyerap unsur hara sehingga penumpukan logam pada akar akan lebih tinggi dibandingkan dengan batang dan daun (non akar). Akar tanaman berinteraksi secara langsung dengan media modifikasi air, sehingga intensitas pemaparan pada akar jadi lebih banyak dari pada daun hal ini sesuai dengan penelitian dari Haryanti dkk. (2009). Adanya kandungan polutan tersebut, dapat berdampak langsung pada enzim yang terlibat dalam mempercepat atau menghambat biosintesis senyawa metabolit primer seperti karbohidrat, lemak dan protein. Senyawa ini berfungsi sebagai bahan respirasi yang menghasilkan pembelahan ATP pada ujung akar, pembelahan meristem yang membentuk tunas baru, penyerapan air untuk inisiasi trasnpirasi pembelahan sel dan stomata. Pada beberapa tumbuhan (termasuk s.molesta) akan menghasilkan metabolit sekunder sebagai hasil pertahanan samping. Konsentrasi logam yang tinggi secara fisiologis pada tumbuhan akan memicu respons dengan membentuk kompleks dengan ion logam dan mencegah logam bereaksi dengan bahan yang sensitif terhadap protoplasma seperti enzim. Sekresi atau penyimpanan logam dalam vakuola-vakuola juga dapat mengurangi efek toksiknya. Ini bertujuan untuk mengurangi efek toksisitas terhadap pertumbuhan sel, jaringan dan morfogenesis (Haryanti et al. 2009).

Tabel 5.2 Pengaruh pemupukan terhadap pertumbuhan tanaman

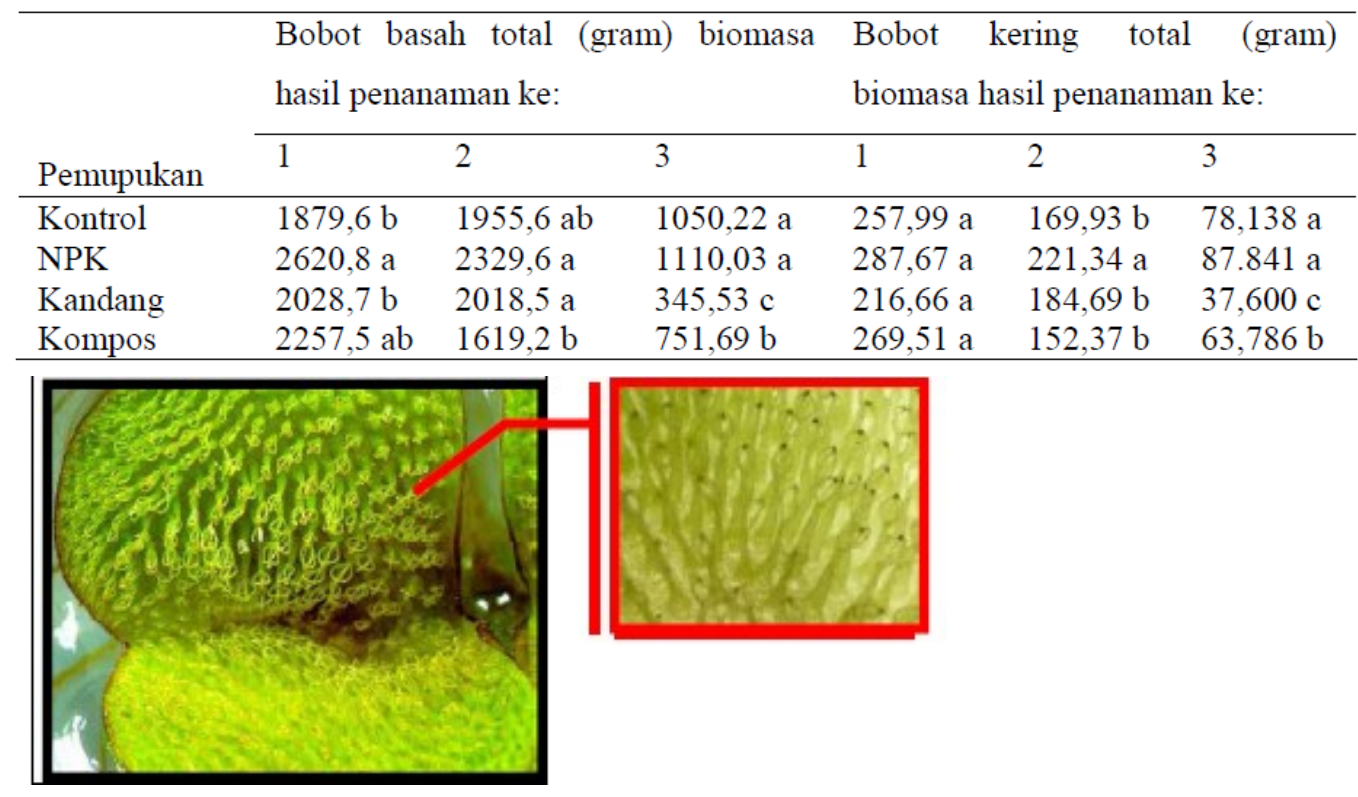

Gambar 5.5 Trikoma pada Daun S. Molesta 
Munculnya beberapa protein baru pada organ daun $S$. molesta diduga karena adanya trikoma pada daun yang dapat mengakumulasi protein tersebut.Trikoma berperan dalam respon fisiologis seperti akumulasi dan detoksifikasi zat beracun ketika tanaman mengalami berbagai kondisi stres (logam berat, garam, ABA (asam absisat) dan suhu dingin) karena memiliki kandungan GSH yang tinggi (substrat Pc sintase) dan memiliki banyak vakuola $(90-95 \%$ dari total volume sel) (Sangman et al. 2002). Dugaan dalam penelitian ini adalah bahwa situs aktif yang terdapat pada biomassa tumbuhan S.molesta merupakan protein yang memiliki satuan asam amino sebagai penyusunnya. Interaksi antara $\mathrm{Pb}^{2+}$ dan $\mathrm{Cd}^{2+}$ dengan adsorben biomassa tanaman S.molesta akibat adanya gaya elektrostatis antara adsorben bermuatan negatif yang bertindak sebagai situs aktif dengan muatan positif ion logam. Ion logam, terutama logam transisi dapat membentuk ikatan dengan senyawa asam amino karena elektron bebas pada atom oksigen terdapat pada gugus fungsi senyawa asam amino dan - $\mathrm{COOH}$ setelah terdeprotonasi. Efektivitas interaksi antara ion logam dengan senyawa asam amino sangat bergantung pada gugus spesiasi yang terkandung dalam larutan. Gugus fungsi - $\mathrm{COOH}$ akan terdeprotonasi menjadi-COO- yang kan digunakan untuk mengikat logam $\mathrm{Pb}^{2+}$ dan gugus fungsi $\mathrm{Cd}^{2+}-\mathrm{COOH}$ dan $-\mathrm{NH}_{2}$ yang dimiliki oleh asam amino dan memiliki spesiasi yang berbeda pada $\mathrm{pH}$ tertentu. Gugus fungsi spesiasi-COOH dan $-\mathrm{NH}_{2}$ dapat dilihat pada Gambar 5.6.

Karena dengan adanya gugus ion $\mathrm{H}^{+}$yang terdapat pada biomassa tumbuhan S.molesta akan mengalami protonasi dan memiliki muatan positif yang sangat reaktif terhadap spesiasi berupa anion dan ion akibat adanya gugus $\mathrm{OH}$ yang dimiliki oleh biomassa tersebut. Tanaman S.molesta mengalami deprotonasi dan memiliki muatan negatif yang sangat reaktif terhadap spesiasi logam berupa kation, seperti $\mathrm{Pb}^{2+}$ dan $\mathrm{Cd}^{2+}$ yang teradsorpsi oleh kelompok senyawa yang aktif dalam biomassa tanaman.

Gugus pada spesiasi asam amino dipengaruhi oleh titik isoelektrik yang dimiliki oleh asam amino tersebut. Dengan mengetahui muatan tersebut, dapat diprediksi titik isoelektrik asam amino akibat protonasi atau deprotonasi pada setiap perubahan $\mathrm{pH}$. Pada titik isoelektrik asam amino akan membentuk zwiterion yang bersifat mengion sempurna ( $\left.+\mathrm{NH}_{3}-\mathrm{CHR}-\mathrm{COO}-\right)$, tetapi tidak memiliki muatan netto. Mekanisme terbentuknya ikatan ion logam $\mathrm{Pb}^{2+}$ dan $\mathrm{Cd}^{2+}$ dengan situs aktif pada biomassa tanaman terjadi pada gugus $-\mathrm{COOH}$ dalam gugus asam amino yang berperan sebagai situs aktif untuk pembentukan ikatan dengan ion logam dan selanjutnya membentuk ikatan yang stabil. Tanaan $S$. molesta kaya akan gugus amino sehingga kapasitas adsorben semakin tinggi

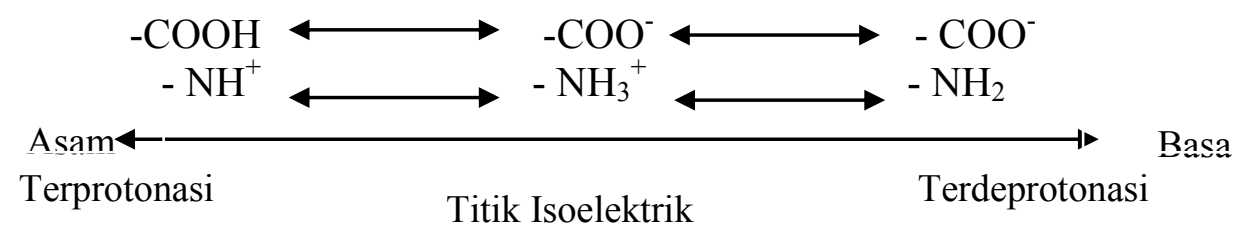

Gambar 5.6 Spesiasi kluster aktif dalam Asam Amino (Lehninger, 1982) 


\section{Nilai Faktor Transfer (FT)}

Nilai Faktor Transfer (FT) merupakan nilai yang menunjukkan kemampuan suatu tumbuhan dalam menyerap logam berat, atau disebut juga dengan Accumulator Metal Species yang efisien apabila hasil analisis perbandingan konsentrasi logam pada jaringan tumbuhan dan media memiliki nilai Tranfer Factor (FT) $>1$ (Tjahaja, 2007). Dari perhitungan faktor transfer (FT) tumbuhan S.molesta, menunjukkan bahwa tumbuhan ini dapat digunakan sebagai fitoremediator tumbuhan logam berat khususnya $\mathrm{Pb}$ dan $\mathrm{Cd}$ dimana pada kondisi berikut tumbuhan S.molesta dapat menyerap logam berat.

Nilai faktor transfer logam $\mathrm{Pb}$ dan $\mathrm{Cd}$ sebagai berikut:

1. Pupuk [NPK] $10 \mathrm{mg} / \mathrm{L},[\mathrm{Pb}] 100 \mathrm{mg} / \mathrm{L}$ dan waktu kontak pada hari ke-14; 21; 28 dan $35(\mathrm{FT}=1283 ; 11: 22 ; 2106$ dan 4376)

2. Pupuk [NPK] $10 \mathrm{mg} / \mathrm{L}$, [Cd] $100 \mathrm{mg} / \mathrm{L}$ dan waktu kontak pada hari ke $7 ; 14$; $21 ; 28$ dan $35(\mathrm{FT}=1.1135 ; 1.30459$; $1.8878 ; 2.70091$ dan 9.56957)

\section{KESIMPULAN}

Berdasarkan data kandungan logam berat ( $\mathrm{Pb}$ dan $\mathrm{Cd}$ ) pada tanaman S.molesta, serapan tertinggi pada akar tanaman dibandingkan non akar dan pengaruh pupuk NPK dengan konsentrasi yang lebih tinggi dapat memberikan pengaruh yang lebih tinggi dalam menyerap logam berat. Nilai FT rata-rata tanaman S.molesta lebih besar dari 1 (FT> 1) maka tanaman dapat digunakan sebagai agen remediator tanaman yang baik.

\section{DAFTAR PUSTAKA}

Darmono, 1995. Logam dalam Sistem Biologi Mahkluk Hidup. Jakarta: Universitas Indonesia Press.
Fitter A.H. dan Hay, R.K.M. (1991), Fisiologi Lingkungan Tanaman. Universitas Gajah Mada, Yogyakarta.

Freedman, B., 1995, "Environmental Ecology”, Second Edition, Academic Press, London

Gardea-Torresdey Jl, Peralta-Videa JR, Rosa GD, Parsons JG (2005). Phytoremediation of heavy metals and study of the metal coordination by X-ray absorption spectroscopy. Coord. Chem. Rev., 249(17-18): 1797-1810.

Gratão PL, Polle A, Lea PJ, Azevedo RA. 2005. Making the life of heavy metal-stress plants a little easier. Functional Plant Biology, 32, 481-494.

Harris, O.P. and Ramelow, J.G. (1990). Binding of Metal Ions by Particulate Biomass Derivated from Chorella vulgaris and Scenedesmus quadricauda. Environ.Sci. and Tech. 24: 220227.

Haryadi, 1996. Heavy metal contents in industrial wastes in Indonesia, in symposium and workshop on heavy metal bioaccumulation, Biotechnology, Gadjah Mada University, Yogyakarta, September 1996

Haryanti, Sri, Nintya Setiari, Rini Budi Hastuti, Endah Dwi Hastuti, dan Yulita Nurchayati. 2009. Respon Fisiologi dan Anatomi Eceng Gondok (Eichornia crassipes (Mart) Solm) di Berbagai Perairan Tercemar. Jurnal Penelitian Sains dan Teknologi. Vol. 10, no 1: 3040. 
Priyanto, B. \& Prayitno, J. 2006. Fitoremediasi sebagai Sebuah Teknologi Pemulihan pencemaran, khususnya logam berat (online). (http://ltl.bppt.tripod.com/sub lab/ifloral.htm, diakses 4 Pebruari 2011).

Sangman, Lee, Jae S. Moon, Leslie L Domier, Schuyler S. Norban. 2002. Molecular Characterization of Phytochelatin Synthase Expression in Transgenic Arabidopsis. Plant. Physiol. Biochem. 40. 727-733.
Tjahaja, Poppy I. 2007. Penyerapan 134Cs dari Tanah oleh Tanaman Bunga Matahari (Helianthus anuus, Less). Jurnal Pusat Teknologi Nuklir Bahan dan Radiometri, BATAN. Bandung.

Wisjnuprapto, A. 1996. Bioremediasi Manfaat dan Pengembangannya. In: Prosiding Pelatihan dan Lokakarya Peranan Bioremediasi dalam Pengelolaan Lingkungan; Cibinong, 24-28 Juni 1996 